\title{
Uji Performa Calon Bibit Sapi Peranakan Ongole Berdasarkan Karakteristik Kuantitatif dan Kualitatif
}

\author{
(Performance Test of Peranakan Ongole Breed Cattle \\ Based on Quantitative and Qualitative Characteristics)
}

\author{
Rasyid A, Luthfi M \\ Loka Penelitian Sapi Potong, Jl. Pahlawan No. 2, Grati, Pasuruan, Jawa Timur \\ luthfi.m888@gmail.com
}

\begin{abstract}
This study aims to determine the results of the performance qualitatively and quantitatively test of Peranakan Ongole breed cattle in Indonesian Beef Cattle Research Station (IBCRS). This activity was conducted at the station of Breeding Management Unit IBCRS using PO weaning cattles consisting of 16 steer and 14 heifer from the selection of breeding programme. Cattle was kept using two group that is steer group and heifers group with the same treatment i.e. feed $\geq 3 \%$ of body weight (dry matter ration) with $30 \%$ forage and $70 \%$ concentrate ratio. Observation on the growth of breed cattles was done by measuring body weight and body size since the animals entering Performance Test Station and monitored every month. The assessment in the performance test is conducted quantitatively by weighing and measure the body weight and observed the body score, body harmony, characteristic match with PO cattle, temperament, body condition score (BCS), reproduction condition and condition of foot and nail. The results of PO cattle at the age of 24-36 months of cows candidate as much as 9 heads with an average height $125.3 \pm 3.0 \mathrm{~cm}$; body weight $261.7 \pm 37.7 \mathrm{~kg}$; ADG $0.37 \pm 0.10 \mathrm{~kg} / \mathrm{head} / \mathrm{day}$; and $\mathrm{PO}$ cattle with mean height $128.9 \pm 2.3$ $\mathrm{cm}$, body weight $306.8 \pm 44.0 \mathrm{~kg}$, and ADG $0.50 \pm 0.08 \mathrm{~kg} / \mathrm{head} / \mathrm{day}$.
\end{abstract}

Key Words: Breed Superior, Performance Test, PO Cattle

\begin{abstract}
ABSTRAK
Penelitian bertujuan untuk mengetahui hasil uji performa calon bibit sapi PO di kandang percobaan Loka Penelitian Sapi Potong (Lolitsapi) secara kualitatif dan kuantitatif. Kegiatan ini dilakukan di kandang UPBU (Unit Pengelola Bibit Unggul) Lolitsapi menggunakan sapi PO lepas sapih yang terdiri dari 16 ekor sapi jantan dan 14 ekor sapi betina dari hasil seleksi kegiatan pemuliaan. Ternak dipelihara menggunakan dua kandang kelompok yaitu kelompok sapi jantan dan kelompok sapi betina dengan perlakuan yang sama yaitu pakan $\geq 3 \%$ dari bobot badan (BK ransum) dengan perbandingan hijauan $30 \%$ dan pakan penguat $70 \%$. Pengamatan terhadap pertumbuhan bibit ternak dilakukan dengan cara pengukuran terhadap bobot badan dan ukuran tubuh sejak masuk Stasiun Uji Performa (SUP) dan dilakukan monitoring setiap bulan. Penilaian dalam uji performa dilakukan secara kuantitatif yaitu dilakukan penimbangan dan pengukuran terhadap bobot badan dan secara kualitatif dengan skoring tampilan tubuh, keserasian tubuh, kesesuaian karakteristik dengan rumpun sapi PO, temperamen, skor kondisi tubuh (SKT), kondisi reproduksi serta kondisi kaki dan kuku. Hasil penelitian sapi PO pada umur 24-36 bulan memiliki tinggi badan sapi jantan $\geq 127 \mathrm{~cm}$ dan sapi betina $\geq 121 \mathrm{~cm}$; calon bibit sapi betina sebanyak 9 ekor dengan rata-rata tinggi badan $125,3 \pm 3,0 \mathrm{~cm}$; bobot badan $261,7 \pm 37,7 \mathrm{~kg}$ dengan $\mathrm{PBBH} 0,37 \pm 0,10$ $\mathrm{kg} / \mathrm{ekor} / \mathrm{hari}$; dan sapi $\mathrm{PO}$ jantan dengan rata-rata tinggi badan $128,9 \pm 2,3 \mathrm{~cm}$, bobot badan $306,8 \pm 44,0 \mathrm{~kg}$ dengan PBBH 0,50 $\pm 0,08 \mathrm{~kg} / \mathrm{ekor} / \mathrm{hari}$.
\end{abstract}

Kata Kunci: Bibit Superior, Uji Performa, Sapi PO 


\section{PENDAHULUAN}

Sapi Peranakan Ongole (PO) merupakan sumber daya genetik sapi potong lokal Indonesia yang perlu dilindungi dan dilestarikan berdasarkan peraturan Menteri Pertanian nomor: 2841/Kpts/LB.430/8/2012. Sapi PO tersebar luas pada beberapa sentra sapi potong dengan populasi terbesar di Pulau Jawa khususnya di Jawa Timur (Astuti 2004), populasi dan produktivitasnya saat ini mengalami penurunan akibat persilangan dengan Bos taurus yang telah berlangsung lama. Kegiatan persilangan yang telah berlangsung lama dan tidak terprogram dengan baik serta dengan target yang belum pasti, akan menjadi ancaman bagi kelestarian plasma nutfah sapi potong lokal (Astuti 2004).

Upaya peningkatan mutu genetik sapi potong lokal pada usaha peternakan rakyat adalah melakukan seleksi dan pembentukan kelompok penghasil bibit atau breeding stock (Thalib 2001); serta melakukan uji performa terutama untuk mendapatkan pejantan unggul yang mempunyai peran penting sebagai sumber semen beku di pusat pembibitan (breeding center) maupun sebagai pejantan pemacek pada pusat-pusat pembibitan maupun pada kelompok pengembangan sapi potong rakyat.

Penilaian uji performa terhadap bibit sapi PO dalam penelitian ini dilakukan berdasarkan prestasi kinerja secara kuantitatif dan kualitatif. Secara kuantitatif dilakukan melalui penimbangan bobot badan dan pengukuran ukuran tubuh, sedangkan secara kualitatif penilaian dilakukan terhadap tampilan umum, keserasian tubuh, kesesuaian dengan karakteristik sapi PO, temperamen, skor kondisi tubuh (SKT), bentuk kaki dan kuku, kondisi skrotum bagi sapi jantan dan kondisi ambing untuk sapi betina. Penilaian (judging) terhadap bibit sapi potong dapat dilakukan melalui pengamatan fisik (secara kuantitatif) terhadap bobot badan, ukuran tubuh dan lingkar scrotum (untuk ternak jantan) dan secara kualitatif dilakukan terhadap warna bulu dan bentuk tubuh. Penilaian lainya dilakukan terhadap temperamen dan keserasian ternak (Hinch 1997; Voisinet et al. 1997; Rianto \& Purbowati 2009).

Peran strategis sapi potong lokal dalam upaya mewujudkan ketahanan pangan nasional di antaranya sebagai penghasil daging, penyedia bibit dan bakalan pada usaha peternakan rakyat. Akan tetapi populasi dan produktivitasnya disinyalir mengalami penurunan akibat pemotongan sapi betina produktif, persilangan dengan Bos taurus yang telah lama berlangsung, di samping itu ketersediaan bibit sapi lokal yang berkualitas masih sulit ditemukan di peternak, karena didominasi oleh sapi persilangan. Pengembangbiakan sapi potong lokal di beberapa wilayah pada umumnya menggunakan bibit (jantan dan betina) yang kualitasnya relatif rendah serta keterbatasan jumlah pejantan unggul.

Kebutuhan daging sapi potong dalam negeri belum dapat terpenuhi dari produksi dalam negeri, yang setiap tahun terus meningkat. Sementara ketersediaan bibit dan bakalan sapi potong lokal sampai saat ini belum dapat terpenuhi dari usaha pembibitan sapi potong rakyat (Hadi \& Ilham 2002), sehingga impor sapi bakalan dari negara Australia tetap berlangsung. Laju permintaan daging sapi potong yang lebih tinggi dari populasinya, secara alamiah akan mendorong pengurasan sumber bibit untuk dijadikan sebagai penghasil daging (Soetanto 2008).

Beberapa permasalahan yang dihadapi dalam sistem perbibitan sapi potong antara lain terbatasnya pelaku usaha untuk pembibitan dan kelembagaan pembibitan yang ada belum memadai. Sistem perbibitan nasional diperlukan untuk menjamin ketersediaan bibit yang memenuhi kebutuhan sesuai dengan jumlah, standar mutu, syarat kesehatan dan keamanan hayati serta terjaga kontinyuitasnya yang dapat menjamin usaha budidaya peternakan.

Upaya untuk penyediaan bibit unggul khususnya pejantan antara lain dilakukan dengan uji performa. Uji performa merupakan salah satu metode pengujian untuk memilih ternak bibit berdasarkan sifat kualitatif dan kuantitatif yang meliputi pengukuran, 
penimbangan dan penilaian (Ditjennak 2007). Penelitian ini bertujuan untuk mengetahui hasil uji performa calon bibit sapi PO di kandang percobaan Loka Penelitian Sapi Potong secara kualitatif dan kuantitatif.

\section{MATERI DAN METODE}

\section{Lokasi penelitian}

Kegiatan penelitian ini dilakukan di kandang percobaan Loka Penelitian Sapi Potong, di Grati Pasuruan, Jawa Timur.

\section{Materi penelitian}

Materi yang digunakan adalah sapi PO lepas sapih hasil seleksi kegiatan pemuliaan yang selanjutnya dikelola dalam kegiatan Unit Pengelola Bibit Unggul (UPBU) sebanyak 30 ekor sapi potong yang terdiri dari 16 ekor sapi jantan dan 14 ekor sapi betina mulai umur lepas sapih sampai umur 24-36 bulan yang ditempatkan dalam dua kandang kelompok berdasarkan jenis kelamin.

\section{Metode penelitian}

Uji performa dimaksudkan untuk mengevaluasi potensi genetik calon-calon bibit dengan meminimalisir pengaruh lingkungan seperti pengaruh pakan, manajemen, dll. Pengujian dilakukan berdasarkan pedoman pelaksanaan uji performa dari Dirjen Peternakan dan Kesehatan Hewan (Ditjenak 2012). Uji performa (performance test) menggunakan dua kandang kelompok yaitu kandang kelompok sapi jantan dan kandang kelompok sapi betina.

Ternak dipelihara dengan perlakuan (kondisi) yang sama meliputi manajemen pakan, perkandangan, dan pengelolaan kesehatan. Pemberian pakan sebesar $\geq 3 \%$ dari bobot badan (BK ransum) dengan perbandingan hijauan sebesar 30\% dan pakan penguat sebesar $70 \%$ yang mengandung protein kasar sebesar 10-12\%, serat kasar berkisar antara $14-20 \%$, TDN 50-60\% dan abu kurang dari 10\%. Pakan penguat disusun dari hasil ikutan pertanian dan perkebunan (dedak padi, onggok kering, kulit kopi, bungkil sawit, bungkil kopra, tumpi jagung dan lain-lain) dengan tambahan mineral (kapur dan garam).

Pengamatan terhadap pertumbuhan bibit ternak dilakukan dengan cara pengukuran terhadap bobot badan dan ukuran tubuh sejak masuk stasiun uji performa (SUP) dan dilakukan monitoring setiap bulan. Penilaian dalam uji performa meliputi:

(1) Penilaian kuantitatif yaitu melakukan penimbangan dan pengukuran terhadap bobot badan, tinggi badan, tinggi pinggul, panjang badan, dan lingkar dada

(2) Penilaian kualitatif menggunakan skoring terhadap:

a. Tampilan umum meliputi kondisi garis punggung dari leher sampai dengan ekor, berdiri tegak pada ke empat kaki, proporsi seimbang dan tidak cacat fisik.

b. Keserasian atau keharmonisan tubuh meliputi kesesuaian bobot dengan umur; kepala berimbang dengan bagian tubuh yang lain; badan panjang, semetris dan penuh otot; sedikit tegap dan kompak.

c. Kesuaian karateristik dengan sapi PO meliputi mempunyai warna bulu putih sampai dengan abu-abu, bergumba dan bergelambir, bulu ekor hitam, dan bulu sekitar mata hitam.

d. Temperamen meliputi pendiam, tenang dan gelisah.

e. Kondisi organ reproduksi meliputi kondisi testis (jantan) dan ambing susu (betina). 
f. Kondisi kaki dan bentuk kuku.

g. Skor kondisi tubuh (SKT) 1-9 (Nicholson \& Butterworth 1986).

Penilaian kualitatif menggunakan skor dengan kriteria yaitu skor 1 adalah jelek, skor 2 adalah sedang dan skor 3 adalah baik.

Tabel 1. Penilaian secara kuantititif dan kualitatif sapi PO

Peharmonisan/keserasian Parameter dan gambar

Sumber: BSN (2015); Nichols et al. (1996)

Data dianalisis secara deskriptif berdasarkan hasil rataan dan standar deviasi populasi dasar bibit sapi PO.

\section{HASIL DAN PEMBAHASAN}

\section{Karakteristik kuantitatif}

Hasil penelitian menunjukkan bahwa karakteristik kuantitatif sapi PO calon bibit memiliki tinggi badan kategori A sebanyak 8 ekor dengan rata-rata bobot badan dan tinggi badan masing-masing sebesar $306,8 \pm 44,0 \mathrm{~kg}$ dan $128,9 \pm 2,3 \mathrm{~cm}$; dan yang memiliki tinggi badan kategori $\mathrm{B}$ sebanyak tujuh ekor dengan rata-rata bobot badan dan tinggi badan masing-masing sebesar 204,1 $\pm 30,6 \mathrm{~kg}$ dan 118,8 $\pm 6,5 \mathrm{~cm}$; (Tabel 2). 
Tabel 2. Performa sapi PO berdasarkan karakteristik secara kuantitatif

\begin{tabular}{lcccc}
\hline \multirow{2}{*}{ Variabel pengamatan } & \multicolumn{2}{c}{ Jantan } & \multicolumn{2}{c}{ Betina } \\
\cline { 2 - 5 } & Kategori A & Kategori B & Kategori A & Kategori B \\
\hline Jumlah (N) & 8 & 7 & 9 & 5 \\
Umur (bulan) & $29,70 \pm 6,00$ & $17,80 \pm 3,60$ & $22,60 \pm 2,30$ & $22,30 \pm 3,90$ \\
Bobot badan (kg) & $306,80 \pm 44,00$ & $204,10 \pm 30,60$ & $261,70 \pm 37,70$ & $181,80 \pm 34,10$ \\
PBBH (kg/ekor/hr) & $0,50 \pm 0,08$ & $0,31 \pm 0,09$ & $0,37 \pm 0,10$ & $0,24 \pm 0,06$ \\
Ukuran tubuh & & & & \\
Tinggi badan (cm) & $128,90 \pm 2,30$ & $118,80 \pm 6,50$ & $125,30 \pm 3,00$ & $117,10 \pm 3,40$ \\
Tinggi pinggul $(\mathrm{cm})$ & $134,00 \pm 2,80$ & $125,00 \pm 3,90$ & $131,70 \pm 2,50$ & $126,30 \pm 7,50$ \\
Panjang badan $(\mathrm{cm})$ & $121,90 \pm 8,30$ & $105,60 \pm 5,90$ & $117,60 \pm 3,30$ & $107,20 \pm 3,60$ \\
Lingkar dada $(\mathrm{cm})$ & $157,30 \pm 7,90$ & $134,90 \pm 7,10$ & $148,90 \pm 10,00$ & $129,10 \pm 5,90$ \\
\hline
\end{tabular}

Kategori tinggi badan berdasarkan SNI 7651.5 (BSN 2015); Kelas I: Sapi PO jantan tinggi badan $128 \mathrm{~cm}$; Kelas II: Sapi PO jantan tinggi badan $125 \mathrm{~cm}$; Kelas I: Sapi PO betina tinggi badan minimal $119 \mathrm{~cm}$; Kelas II: Sapi PO betina tinggi badan minimal $116 \mathrm{~cm}$

Dari sebanyak delapan ekor bibit sapi PO jantan yang telah memenuhi tinggi badan minimal, sebanyak tiga ekor (nomor 15/46, 15/58 dan 15/91) masih berumur antara 15,618 bulan. Kondisi ini memberi peluang bagi calon pejantan tersebut untuk dapat memperoleh kualitas yang lebih baik setelah memasuki umur yang dipersyaratkan. Sedangkan sebanyak tujuh ekor yang tidak memenuhi persyaratan tinggi badan minimal masih berumur antara 13,0-23,6 bulan. Kondisi ini menunjukkan bahwa untuk mencapai tinggi badan minimal sesuai SNI 2015 pada umur 24 bulan, maka ternak tersebut harus mempunyai laju pertumbuhan optimal hingga pada umur ditetapkan.

Hasil perkembangan bobot badan selama pengamatan menunjukkan bahwa bibit sapi PO jantan yang mempunyai tinggi badan kelas I mempunyai performa bobot badan awal dan bobot badan akhir yang lebih tinggi dibandingkan dengan dengan bibit yang mempunyai tinggi badan kelas II. Begitu pula pada bibit sapi PO betina menunjukkan bahwa perkembangan bobot badan lebih tinggi pada sapi PO yang mempunyai tinggi badan kelas I dibandingkan dengan dengan sapi PO yang mempunyai tinggi badan kelas II (Gambar 1 dan 2). Terjadinya perbedaan capaian pertambahan bobot badan harian (PBBH) yang ditampilkan individu dari masing-masing kelas tinggi badan terjadi karena pada kelas II memiliki umur yang relatif lebih muda dibandingkan dengan kelas I. Hal ini sesuai dengan Hardjosubroto (1994) yang menyatakan bahwa performa produksi ditentukan oleh faktor genetik dan lingkungan.

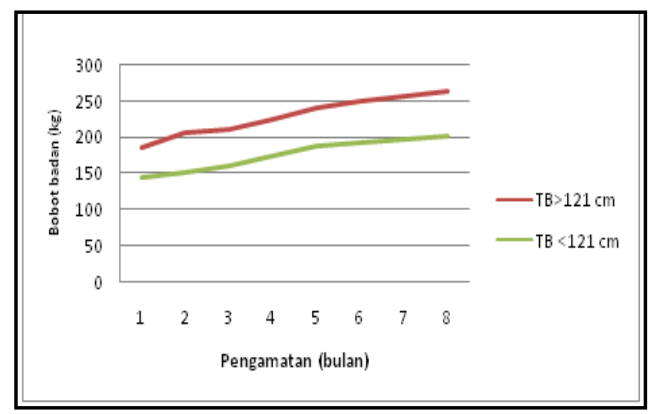

Gambar 1. Perkembangan bobot badan sapi betina pada tinggi badan (TB) yang berbeda

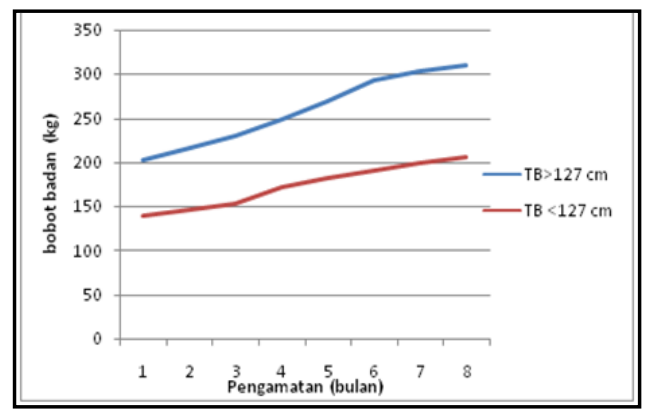

Gambar 2. Perkembangan bobot badan sapi jantan pada tinggi badan (TB) yang berbeda 


\section{Penilaian kualitatif}

Hasil penilaian secara kualitatif terhadap 15 ekor performa sapi PO jantan hasil uji performa menunjukkan bahwa secara umum mempunyai kriteria penilaian sedang sampai baik untuk semua parameter. Penilaian yang kurang baik meliputi bentuk kuku sebanyak 2 ekor $(13 \%)$, skor kondisi tubuh (SKT) dan kondisi skrotum masing-masing sebanyak satu ekor atau sebesar 7\% (Tabel 3). Penilaian skor kondisi tubuh menggunakan skor 1-9 (Nicholson \& Butterworth 1986).

Sedangkan untuk sapi betina, yang mempunyai penilaian performa yang jelek (kurang baik) dilihat dari bentuk kuku sebanyak 5 ekor (36\%), SKT sebanyak 2 ekor (14\%), kondisi ambing sebanyak 3 ekor (21\%) dan temperamen sebanyak 3 ekor (21\%). Secara kualitatif karateristik yang harus dipenuhi oleh sapi PO adalah mempunyai badan yang besar, berpunuk dan bergelambir, berwarna putih s.d. warna krem, bulu sekitar mata hitam dan mempunyai bulu ekor hitam (Ditjenak 2012; BSN 2015). Kurang baiknya performa pada beberapa penilaian kualitatif pada sapi PO jantan maupun betina karena sapi ditempatkan pada kandang kelompok sehingga ada beberapa sapi kalah bersaing yang menyebabkan rendahnya asupan nutrisi yang diterima. Tingkat pemberian pakan pada calon induk/pejantan harus dapat dipergunakan untuk memenuhi kebutuhan pertumbuhan dan kebuntingannya sehingga kebutuhan nutrisi dapat terpenuhi (Parakkasi 1999). Hal ini diperkuat oleh Tilman et al. (1991) yang menyatakan bahwa kuantitas dan kualitas ransum yang diberikan mempengaruhi tinggi rendahnya produksi dan kecepatan pertumbuhan sapi yang sedang tumbuh.

Tabel 3. Hasil penilaian secara kualitatif terhadap performa bibit sapi PO tahun 2016

\begin{tabular}{lccc}
\hline \multirow{2}{*}{ Parameter } & \multicolumn{3}{c}{ Hasil penilaian $(\%)$} \\
\cline { 2 - 4 } Sapi PO jantan & Baik & Sedang & Jelek \\
Tampilan umum & 93 & 7 & 0 \\
Keharmonisan/keserasian tubuh & 80 & 20 & 0 \\
Kesesuaian karakteristik sapi PO & 100 & 0 & 0 \\
Temperamen & 67 & 33 & 0 \\
Kondisi scrotum & 73 & 20 & 7 \\
Skor kondisi tubuh (SKT) & 53 & 40 & 7 \\
Kondisi kaki & 27 & 73 & 0 \\
Bentuk kuku & 74 & 13 & 13 \\
Sapi PO betina & & & \\
Tampilan umum & 71 & 21 & 8 \\
Keharmonisan/keserasian tubuh & 57 & 43 & 0 \\
Kesesuaian karakteristik sapi PO & 79 & 29 & 1 \\
Temperamen & 21 & 58 & 21 \\
Kondisi ambing & 29 & 50 & 21 \\
Skor kondisi tubuh (SKT) & 50 & 36 & 14 \\
Kondisi kaki & 14 & 86 & 0 \\
Bentuk kuku & 50 & 14 & 36 \\
\hline
\end{tabular}

SKT > 7: Baik; SKT 5-7: Cukup; SKT <5: Jelek 
Berdasarkan penilaian secara kuantitatif dan kualitatif, bibit sapi PO jantan yang terpilih memiliki peringkat terbaik mempunyai performa bobot badan, tinggi badan dan PBBH secara berturut-turut untuk peringkat I adalah nomor telinga 14.9.22 yaitu sebesar $379 \mathrm{~kg}, 134 \mathrm{~cm}$ dan 0,60 kg/ekor/hari; peringkat II adalah nomor telinga 14/71 sebesar 352 $\mathrm{kg}, 130 \mathrm{~cm}$ dan $0,54 \mathrm{~kg} / \mathrm{ekor} / \mathrm{hari}$ dan peringkat III adalah nomor 14/81 sebesar $331 \mathrm{~kg}$, $127 \mathrm{~cm}$ dan $0,55 \mathrm{~kg} / \mathrm{ekor} / \mathrm{hari}$. Selanjutnya pejantan muda terpilih tersebut dapat dijadikan calon pejantan yang terbaik.

Menurut Müller \& von Keyserlingk (2006) bahwa temperamen dapat mempengaruhi hampir semua aspek produksi ternak, termasuk pertumbuhan, reproduksi dan kekebalan. Hasil penelitian Handiwirawan \& Tiesnamurti (2015) menyatakan bahwa sifat temperamen berpotensi secara tidak langsung sebagai alat seleksi bagi produksi, reproduksi dan kekebalan. Hal tersebut akan memudahkan peternak dalam melakukan seleksi yang umumnya tidak terbiasa dengan pelaksanaan recording sebagai dasar dan prosedur umum di dalam melakukan seleksi.

\section{KESIMPULAN}

Performa bibit sapi PO umur $>24$ bulan untuk sapi jantan rata-rata tinggi badan dan bobot badan masing-masing $128,9 \pm 2,3 \mathrm{~cm}$ dan $306,8 \pm 44,0 \mathrm{~kg}$ dan untuk sapi betina ratarata tinggi badan dan bobot badan masing-masing $125,3 \pm 3,0 \mathrm{~cm}$ dan $261,7 \pm 37,7 \mathrm{~kg}$. Tiga sapi PO jantan terbaik yaitu peringkat I yaitu nomor 14.9.2, bobot badan $379 \mathrm{~kg}$, tinggi badan $134 \mathrm{~cm}$ dan PBBH 0,60 kg/ekor/hari, peringkat II nomor 14/71 masing-masing sebesar $352 \mathrm{~kg}, 130 \mathrm{~cm}$ dan $0,54 \mathrm{~kg} / \mathrm{ekor} / \mathrm{hari}$, dan peringkat III nomor 14/81 masingmasing sebesar $331 \mathrm{~kg}, 127 \mathrm{~cm}$ dan 0,55 kg/ekor/hari.

\section{DAFTAR PUSTAKA}

Astuti M. 2004. Potensi dan keragaan sumberdaya genetik sapi Peranakan Ongole (PO). Wartazoa. 14 nomor 3:98-106.

BSN. 2015. Bibit Sapi Potong - Bagian 5: Peranakan Ongole (PO). SNI-7351.5. ICS 65.020.30. Jakarta (Indonesia): Badan Standardisasi Nasional.

Ditjennak. 2007. Peraturan Direktur Jenderal Peternakan tentang Petunjuk Teknis Uji Performa Sapi Potong Nasional. Jakarta (Indonesia): Direktorat Jenderal Peternakan.

Ditjen PKH. 2012. Pedoman Pelaksanaan Uji Performan Sapi Potong. Jakarta (Indonesia): Direktorat Jenderal Peternakan dan Kesehatan Hewan.

Hardjosubroto W. 1994. Aplikasi pemuliaan ternak di lapangan. Cetakan II. Jakarta (Indonesia): PT Gramedia Widiasarana.

Hinch GN. 1997. Genetics of behaviour. In: The Genetics of Sheep. Piper L, Ruvinsky A, editors. New York (USA): CAB International. p. 353-374.

Hadi PU, Ilham N. 2002. Problem dan prospek pengembangan usaha pembibitan sapi potong di Indonesia. J Litbang Pertan. 21:148-157.

Handiwirawan E, Tiesnamurti B. 2015. Pertambahan bobot badan sapi Bali dan PO yang digemukkan berdasarkan skor temperamen. Dalam: Noor MN, Handiwirawan E, Martindah E, Widiastuti R, Sianturi RSG, Herawati T, Purba M, Anggraeny YN, Batubara A, penyunting. Teknologi Peternakan dan Veteriner untuk Peningkatan Daya Saing dan Mewujudkan Kedaulatan Pangan Hewani. Prosiding Seminar Nasional Teknologi Peternakan dan Veteriner. Jakarta, 8-9 Oktober 2015. Jakarta (Indonesia): IAARD Press. hlm. 27-33.

Müler R, von Keyserlingk MAG. 2006. Consistency of flight speed and its correlation to productivity and personility in Bos taurus beef cattle. Appl Anim Behav Sci. 99:193-204. 
Nicholson MJ, Butterworth HM. 1986. A Guide to Condition Scoring of Zebu Cattle. Addis Ababa (Ethiopia): International Livestock Centre for Africa.

Nichols DA, Able BV, RH Hiness, Allen DM. 1996. Livestock judging guide. For 4-H Clubs Members. Kansas (USA): Cooperative Extension Service. Kansas State University.

Parakkasi A. 1999. Ilmu makanan dan ternak ruminansia. Jakarta (Indonesia): UI Press. hlm. 371374.

Rianto E, Purbowati E. 2009. Panduan lengkap sapi potong. Jakarta (Indonesia): Penebar Swadaya.

Soetanto H. 2008. Strategi optimasi pemanfaatan sumberdaya dan teknologi tepat guna pertanian untuk meningkatkan pendapatan peternak sapi potong. [Internet]. [Diakses 26 Desember 2016]. http://ntb.litbang.deptan.go.id.

Tillman D, Hartadi H, Prawirokusumo S, Reksohadiprodjo S, Lebdosukojo S.1991. Ilmu makanan ternak dasar. Yokyakarta (Indonesia): Gadjah Mada University Press.

Thalib C. 2001. Pengembangan sistem perbibitan sapi potong nasional. Wartazoa. 11:10-19.

Voisinet BD, Grandin T, Tatum JD, O’Connor SF, Struthers JJ. 1997. Feedlot cattle with calm temperaments have higher daily gains than cattle with excitable temperaments. J Anim. Sci. 75:892-896. 